Sergej Flere

University of Maribor, Slovenia

Rudi Klanjšek

University of Maribor, Slovenia
UDK: 322.2

Оригиналан научни рад

Примљен: 21. 02. 2007.

\title{
SERBIAN ORTHODOX RELIGIOUSNESS: AN EMPIRICAL AND COMPARATIVE PORTRAIT
}

Serbian Orthodoxy was studied empirically by using different measures of religiousness. After an initial placement of Serbian religiousness in the context of WVS data, a sample of south Serbian university students was compared to student samples from three other religions: Bosnian Muslims, and Slovenian Catholics. When using World Values Survey (WVS) measures, results indicated that the Serbian Orthodox proved to be more religious than irreleligious; when using our own survey data and more complex measures, the Serbian Orthodox proved to be more religious than Slovenian Catholics, but less religious than Bosnian Muslims, although Serbian Orthodox affiliates did surpass the normative means on certain items. Mysticism, religious experience and civil religion were not outstanding, in contrast to what might have been expected from the literature (Mitrovic 1995; Vrcan 1995; Tomka 2006). The Serbian Orthodox exhibited a high level of extrinsic psychological religiousness and of guilt religiousness, both of which show a significant positive correlation with trait anxiety.

Key words: Serbian Orthodoxy, religiousness, religious orientation, guilt religiousness, religious consequentiality.

\section{INTRODUCTION}

A review of the relevant literature reveals a noticeable dearth of studies on Serbian Orthodoxy, an Orthodox national confession that comprises both the Serbs in Serbia (ethnic Serbs comprising 83,1\% of the 7577000 population of Serbia), and affiliates in neighboring countries, as well as in the diasporas. In the diasporas, bishoprics are dispersed through North and South America and Australia.

The Serbian Orthodox Church (SOC) was founded, according to official doctrine in 1219, through the endeavors of Saint Sava (Rastko), a member of the then ruling Nemanjić dynasty, who was successful in attaining Serbian Orthodox autocephaly from the Ecumenical Patriarch Manuel Charitopoulos I, who was at that time in exile in Nikaia. Until then, the Nemanjic dynasty was ambivalent in its siding with the Christian East and West. In the period that the Serbs consider their worst and most tragic historical suffering - their five-century subjugation within the Ottoman Empire - the SOC remained the main integrative ethnic factor, much 
Sergej Flere, Rudi Klanšek, Serbian Orthodox Religiousness...

hailed later in nationalist literature as the soundest pillar and guarantor of Serbianhood (Bogdanović 1991: 36-37; Đorđević 1993: 33-43).

After national emancipation in the 19th century, the SOC joined the ideology of claiming a "greater Serbia", which formed a major thread of modern Serbian history (Božić, Ćirković, Dedijer and Ekmečić 1972: 372). But the SOC was not as subservient to the state as one might assume from the usual Ceasaropapist pattern. There were numerous disputes with the state, possibly the major one pertaining to the Concordate with the Holy See that the state had signed in 1938 and which excommunicated ministers and parliamentary deputies (Božić et al. 1972: 441).

After the fall of Communism the SOC again, on the eve of and during the postYugoslav wars, promoted the idea of a "greater Serbia", possibly being its greatest intellectual promoter ${ }^{1}$.

At present, the Orthodox comprise $84.9 \%{ }^{2}$ of the population of Serbia; the two major denominational minorities in Serbia are Muslims (3.2\%) and Roman Catholics (5.5\%) (RZSRS 2003).

As to empirical religiosity, Serbian authors writing within their scholarly comm.unity have rarely made use of a comparative framework (Đorđević 2000; Radisavljević-Ćiparizović 2002), with the partial exception of Blagojević (2005). Studies on Eastern Orthodoxy (Makrides 1999) did not consider whether or not Serbian Orthodoxy was distinct within Orthodoxy. In his work critical of Serbian Orthodoxy, however, Vrcan (1995) did stress that the origin of the distinctiveness of Serbian Orthodoxy has to do with its ante-murale position towards Roman Catholicism and Islam. On the other hand, the Serbian sociologist Blagojević maintained the basic similarity, both institutionally and in the sociological empirical sense, between Serbian and Russian Orthodoxy (Blagojević 2005: 391).

Nevertheless, Eastern Orthodoxy in general was alleged to have peculiarities in its religious practice, with less stress on dominical ritual and more on holidays (Đorđević 2000). Moreover, since various authors have argued that Eastern Orthodoxy as a whole has not been exposed to western influences - the Renaissance, scientific development and general societal modernization (see Makrides 1999; Stark 2001; Tomka 2006), Tomka has pleaded for a »special methodology « in the study of Eastern Orthodoxy. The same need was implicitly expressed by Đorđević (1998), who noted that Serbian Orthodox consciousness has been contaminated historically by paganism and other extra-Christian components.

These positions outline some of the possible empirical peculiarities of Serbian Orthodoxy, while questioning whether the above assertions truly correspond to

\footnotetext{
${ }^{1}$ Statements by the SOC prelates to that effect are numerous, as well as blessings of military and para-military units and their exploits, particularly those in Bosnia. An overview of the doctrine is presented in Mladenović, R. and Ćulibrk, J. (Eds.) (1996).

${ }^{2}$ The official statistics in Serbia apply the rubric of 'Eastern Orthodox', thus compounding other Orthodox groups (Rumanian, Macedonian) along with the Serbian Orthodox (RZSRS 2003).
} 
Социолошки преглед, vol. XLII (2008), nо. 1, стр. 27-44

reality. Consequently, the main aim of the current study was to compare Serbian Orthodox religiousness to other neighboring religious cultures in order to see whether such peculiarities did exist. More specifically, the current study looked into the issue of whether civil religion was as pronounced as Vrcan (1995) argued; whether martyrdom within sacrifice was as present as Vrcan (1995) and Mitrović (1996) held; whether mysticism and religious experience were as commonplace as might be expected of Orthodoxy (Tomka 2006); whether there were any unique features of religious orientation that have thus far not been studied and whether there were any distinctive traits of this religious belief not foreseen by the theory. Tomka (2006), for example, has previously argued that "Eastern European religion eludes the criteria of the western sociology of religion, as all new phenomena do" (2006: $265)$ and that "one needs different indicators and research methodology" (2006: 251).

\section{METHOD}

\section{Sample}

First, data from the World Value Survey 1999-2001 data was used to determine the location of Serbia on one central measure of religiousness (Stark 2004). Specifically, samples from 41 European countries with a Christian tradition were used (for European Christian countries $n=48603$; for Serbia $n=1200$ ) (Inglehart et al. 2004); the measure used was 'How important is God in your life?', which allowed for a range of answers from 1 (not at all important) to 10 (most important) and which was considered by Stark as fundamental to the study of religion and its impact (Stark 2001: 624).

Next, to further study Serbian Orthodox religiousness from a comparative perspective, data were collected from undergraduate university students, primarily in the social sciences, in environments with predominant and traditional religions representing three of the major religions: Maribor, Slovenia $(n=470$, Roman Catholic), Sarajevo, Bosnia and Herzegovina $(\mathrm{n}=439$, Muslim) and Niš, Serbia $(n=427$, Serbian Orthodox). The mean age for the Slovenian sample was 20.3 years $(\mathrm{SD}=1.3), 20.4$ years $(\mathrm{SD}=1.5)$ for the Serbian sample, and 20.7 years $(\mathrm{SD}=1.8)$ for the Bosnian sample. The data collection was carried out in 2005. In all of these samples women formed the majority. The number of men varied from 33.9 percent in the Bosnia and Herzegovina sample to 39.6 percent in the Slovenian sample. In all of the analyses herein, only affiliates with the major religion were taken into consideration, comprising a high percentage in all cases: 76.8 percent for the Slovenian sample, 89.8 percent for the Bosnian sample, and 92.7 percent for the Serbian sample.

The choice of samples permitted detailed exploration of religious traditions that are neighbor to the Serbian Orthodox. The choice of university undergradu- 
Sergej Flere, Rudi Klanšek, Serbian Orthodox Religiousness...

ates, although differing from general population samples, may enhance comparability, owing to the homogenization of age, educational level and social position.

\section{Measures}

1. Religious belief: The scale of religious belief was assessed by five pro-trait items on a five-point scale. The scale proved internally consistent (compound sample C. Alpha $=.86$, Serbian Orthodox sample $=.78)$. The range of the scale was 5 (absence of belief) to 25 (maximum belief presence).

2. Religious orientation: Religious orientation was assessed by eleven pro-trait items on a five-point scale that tapped into both intrinsic (five items) and extrinsic religious orientation (six items) (Allport and Ross 1967). Items used were taken from the Gorsuch and McPherson Intrinsic/Extrisnic revised scale (1989). We omitted the original three extrinsic social (Es) items and limited ourselves to five pro-trait intrinsic (I) and three extrinsic personal items (Ep; see Appendix).

The scales proved internally consistent (C. Alphas for compound sample .80 (intrinsic scale) and .72 (extrinsic personal scale), and .78 and .73 for the Serbian Orthodox sample).

3. Other-worldly orientation: This variable explicitly indicated the renouncing of this world in favor of the "other", that is in favor of the world after consummation, as alleged of the Orthodox by Mitrović (1995) and Tomka (2006; see Appendix). Other-worldly orientation was assessed by two pro-trait items on a five-point scale. C. Alpha for the compound sample amounted was .70 , for the Serbian Orthodox sample $=.72$. The scale had a range of $2-10$.

4. Readiness for religious sacrifice: As noted by Glock and Stark (1965), religiousness includes commitment and consequentiality, meaning the readiness to carry out religious expectations, particularly at the expense of certain worldly goods. In other words, to attain God's favor and benevolence, every believer needs to commit certain deeds (and to renounce committing others). Bearing in mind the allegations (Mitrović 1995; Tomka 2006; Vrcan 1995) that Serbian Orthodoxy was peculiar on the issue of martyrdom, we tested items indicating religious sacrifice, indicating a readiness to commit deeds on the basis of religious motives. More specifically, we tested the readiness of respondents to carry out seven religiously meaningful deeds, which have a meaning in all of the observed religions, although in varied forms. These deeds pertained to varied areas of life, and were assessed individually.

5. Civil religion: The civil religion concept refers to a set of values, norms, beliefs and attitudes by which a given society is sacralized and its substance is comprehended in a transcendent way, the society being ascribed a transcendent mission, and its political authority having a charismatic dimension. The modern version of the concept is linked to Bellah (1967), who argued that civil religion was a necessary, integrative cultural element in every society - at least every modern one - and that it was distinguishable from other related measures of religiousness. 
Соччиолошки преглед, vol. XLII (2008), no. 1, стр. 27-44

In applying the concept of civil religion, it was evident that it entailed some linking of nation, of state, of ethnic group and of sovereign political authority to some principle that was higher than the empirical, the observable or the human, tending towards finding a metaphysical, transcendent, religious or theistic explanation and legitimation of secular phenomena. In arriving at a working definition of civil religion, it did not suffice to say that we agreed with Bellah's classic statement that civil religion is "a set of religious beliefs, symbols and rituals growing out of the American historical experience interpreted in the dimension of transcendence" (1968: 389). We followed Coleman's somewhat more precise definition of civil religion, as phrased by Gehrig, where civil religion is seen as »the religious symbol system which relates the citizen's role and the ...society's place in space, time and history to the conditions of ultimate existence and meaning " (1981: 52).

Our scale (Flere and Lavrič 2007), within the above conceptual delimitations, contained five pro-trait items with values between 1 and 5. Items were very general in nature (see Appendix). The scale proved internally consistent (C. Alpha for the compound sample was .81 , and .78 for the Serbian sample). The range of the scale was $5-25$.

6. Trait anxiety: We studied anxiety as a trait and not as a state, by the StateTrait Anxiety Inventory (Spielberger 1983). Trait anxiety, according to Spielberger denotes relatively stable individual differences in anxiety proneness and refers to a general tendency to respond with anxiety to perceived threats in the environment (1983; see Appendix). The scale proved internally consistent (C. Alpha for compound sample amounted to .89 , and .88 for the Serbian Orthodox sample).

\section{FINDINGS}

\section{Initial location of Serbian Orthodox religiousness from a European perspective}

Results from the single-item analyses ("How important is God in your life?"; $1=$ God totally irrelevant in the respondent's life, $10=$ God is of the utmost relevance) indicated that the respondents from Serbia could be located near the centre when comparing them with respondents living in other European countries with a Christian tradition. Specifically, respondents from Serbia exhibited a mean of $\mathrm{M}=6.07 \quad(\mathrm{SD}=3.08)$, ranking $23^{\mathrm{rd}}$ among 41 European countries with a traditional Christian background.

The mean score for Serbia was similar ( $p>.05)$ to the mean score obtained for neighboring Montenegro $(\mathrm{M}=6.36, \mathrm{SD}=3.09)$ and significantly lower $(\mathrm{p}<.001)$ than the mean score obtained for neighboring Croatia $(M=7.20, S D=2.79)$, Macedonia $(\mathrm{M}=7.66, \mathrm{SD}=2.87)$, and Romania $(\mathrm{M}=8.83, \mathrm{SD}=2.17)$, the last of which proved to be one of the most religious countries within Christian Europe. The mean score for Serbia rose if only Orthodox affiliates were taken into consideration $(\mathrm{M}=6.36$; $\mathrm{SD}=2.92$ ) (79.1 percent of the sample identified themselves as Orthodox affiliates, 
Sergej Flere, Rudi Klanšek, Serbian Orthodox Religiousness...

the rest being mostly other affiliates and some being non-affiliated). In relation to Russia, the country whose population has the highest number of the Orthodox (48,5 percent of the sample identified themselves as Orthodox affiliates), the mean score for Serbia affiliates was significantly lower $(\mathrm{p}<.001)$ than the score obtained for Russian affiliates $(\mathrm{M}=7.08, \mathrm{SD}=2.54)$.

Results thus indicated that the level of religiousness in Serbia and among the Serbian Orthodox was not something exceptional; on the contrary, it was close to the average for Christian Europe, and this was after an alleged religious revival (Radisavljević-Ćiparazović 2002; Blagojević 2005). In other words, although the mean level of religiousness rose after the collapse of Communism, this rise still did not bring Serbian Orthodoxy above what could be called the European average.

\section{Serbian Orthodox, Slovenian Catholics and Bosnian Muslims - A Comparative View}

\section{Religious belief}

Turning to our own sample survey, overall findings indicated the following: the Serbian Orthodox attained a mean score of 16.2, in contrast to Bosnian Muslims who attained a mean score of 23.3 - still ahead of fellow Central European but Catholic Slovenians. This indicated that the Serbian Orthodox registered a magnitude of religious belief just above the normative mean. This was in line with the initial WVS findings, thus not supporting assertions on the exceptionalism of Eastern Orthodoxy.

\section{Religious orientation}

In terms of religious orientation, we present here only the distribution of predominant orientation within the country confessional samples, according to the median-split method, as suggested by Donahue $(1985)^{3}$.

Results from Table 1 (see below) indicated that each of the three samples attained a peak in relative presence within a different religious type. Among the Serbian Orthodox, it was psychological extrinsicness that made them stand out among the samples, indicating a psychological situation demanding such a prevalence of religiousness. Still, even though this orientation attained the highest score among the Serbian Orthodox, it was not the most frequent orientation within this group.

\footnotetext{
${ }^{3}$ A fourfold typology of personal extrinsics, intrinsics, indiscriminate pro-religious and nonreligious subjects was constructed. The first group was high on personal extrinsic religiosity, but low on intrinsic religiosity; the second were high on intrinsic religiosity, but low on the personal extrinsic one; the third group were high on both types of religious motivation, and the last were low on both types of religious motivation (Donahue 1985: 420-421).
} 
Сочиолошки преглед, vol. XLII (2008), nо. 1, стр. 27-44

TABLE 1: Relative shares of particular religious intrinsic and extrinsic types, by country confessional samples

\begin{tabular}{|c|c|c|c|c|c|}
\hline $\begin{array}{l}\text { Country samples of } \\
\text { affiliates/ } \\
\text { Religious } \\
\text { orientation }\end{array}$ & Non-religious & $\begin{array}{l}\text { Indisriminate } \\
\text { pro-religious }\end{array}$ & Intrinsics & $\begin{array}{l}\text { Personal } \\
\text { extrinsics }\end{array}$ & TOTAL \\
\hline $\begin{array}{l}\text { Bosnian Muslims } \\
(\mathrm{N}=390)\end{array}$ & 13.1 & 66.2 & 6.1 & 14.6 & 100 \\
\hline Serbian Orthodox & & & & & \\
\hline$(\mathrm{N}=360)$ & 38.7 & 29.7 & 6.1 & 25.5 & 100 \\
\hline Slovenian Catholics & & & & & \\
\hline$(\mathrm{N}=397)$ & 66.2 & 11.4 & 4.6 & 17.8 & 100 \\
\hline
\end{tabular}

Notes: Data expressed as a percentage of the total within each sample.

\section{Other-worldly orientation}

Next, the other-worldly orientation was tested. As noted earlier, this was done because Orthodoxy was often considered to be mystical, to be lacking the rationalization experienced by Western Christianity, and to be more true to the original, early Christian teachings. Furthermore, there is the figure of speech describing the Serbs as "heavenly people", who opt for a "commonwealth of heaven" and thus renounce this-worldly goods (Mitrović 1995).

Results from Table 2 (see below) indicated that the other-worldly orientation was a strict measure of religiousness where the Serbian Orthodox attained the lowest overall mean. These results did not change even when only very religious respondents were compared. This contradicted any allegation that Serbs opt doctrinally for the other-worldly "commonwealth of heaven". Moreover, it seemed that the overall level of religiousness within an environment explained the particular differences (and not e.g., religious belief), since it persisted even when control for an individual respondent's religiousness was employed. This implied that the issue of whether an environment was "a moral community" (Stark, Kent and Doyle 1982) might have played a significant role, which was not the Serbian case. 
Sergej Flere, Rudi Klanšek, Serbian Orthodox Religiousness...

TABLE 2: Means for the other-worldly orientation scale, by country confessional samples

\begin{tabular}{|c|c|c|c|}
\hline COUN & $\begin{array}{l}\text { RY SAMPLE } \\
\text { ILIATES }\end{array}$ & Mean & Std. Deviation \\
\hline \multicolumn{2}{|c|}{$\begin{array}{l}\text { Bosnian Muslims } \\
(n=390 / 363)\end{array}$} & $5.4^{\mathrm{c}} / 5.8^{\mathrm{c}}$ & $2.3 / 2.3$ \\
\hline \multicolumn{2}{|c|}{ Serbian Orthodox } & $3.2^{\mathrm{a}} / 4.2^{\mathrm{a}}$ & $1.6 / 2.0$ \\
\hline \multicolumn{2}{|c|}{$\begin{array}{l}\text { Slovenian Catholics } \\
(\mathrm{n}=395 / 94)\end{array}$} & $3.6^{\mathrm{b}} / 4.4^{\mathrm{a}}$ & $1.7 / 2.0$ \\
\hline \multicolumn{4}{|c|}{$\begin{array}{l}\text { Notes: Range: } 2 \text { (full rejection of other-worldly orientation) - } 10 \text { (maximum acceptance of other-worldly } \\
\text { orientation). } \\
\text { Figures before the slash indicate data for the entire samples of affiliates, whereas the figures after the } \\
\text { slash indicate data for very religious respondents only (religious belief }=5 \text {, on } 1-5 \text { pro-trait scale). } \\
\text { For each group, the mean with a different superscript letter is significantly different at } p<.05\end{array}$} \\
\hline \multicolumn{4}{|c|}{$\begin{array}{l}\text { Next, the analysis of a single item (I have often had a strong sense of a Divine } \\
\text { presence), chosen from Gorsuch and McPherson's list (1989; see Appendix, at the } \\
\text { end of paper), formulated as an indicator of mystical experiences, which allegedly } \\
\text { should be intrinsic to Orthodoxy (Tomka 2006), provided no support for such a } \\
\text { claim (see Table 3). }\end{array}$} \\
\hline
\end{tabular}

TABLE 3: Means for agreement with the statement »I have often had a strong sense of a Divine presence $\ll$, by country confessional samples

\begin{tabular}{llc}
\hline COUNTRY SAMPLE OF AFFILIATES & Mean & Std. Deviation \\
\hline $\begin{array}{l}\text { Bosnian Muslims } \\
(\mathrm{n}=391 / 363)\end{array}$ & $4.0^{\mathrm{c}} / 4.0^{\mathrm{c}}$ & $14 / 1.2$ \\
$\begin{array}{l}\text { Serbian Orthodox } \\
(\mathrm{n}=358 / 197)\end{array}$ & $2.6^{\mathrm{a}} / 3.4^{\mathrm{a}}$ & $1.4 / 1.2$ \\
$\begin{array}{l}\text { Slovenian Catholics } \\
(\mathrm{n}=296 / 94)\end{array}$ & $2.1^{\mathrm{b}} / 3.1^{\mathrm{b}}$ & $1.1 / 1.2$ \\
\hline
\end{tabular}

Notes: $\quad$ Range: 1 strongly disagree -5 strongly agree.

Figures before the slash indicate data for the entire samples of affiliates, whereas the figures after the slash indicate the data for very religious respondents only (religious belief $=5$, on 1-5 pro-trait scale).

For each group, the mean with a different superscript letter is significantly different at $\mathrm{p}<.05$. 
Соччиолошки преглед, vol. XLII (2008), no. 1, стр. 27-44

Thus, it is evident that those respondents leadings' on average in agreement with this statement were the Bosnian Muslims. The Serbian Orthodox were slightly above the normative mean, which in turn indicated that experiencing God was not unusual. However, as noted before, they lagged significantly $(p<.001)$ behind the Bosnian Muslims.

\section{Readiness for religious sacrifice}

As noted before, many authors (see for example, Mitrović 1995; Tomka 2006; Vrcan 1995) argued that Serbian Orthodoxy was peculiar on the issue of martyrdom. Consequently, we tested whether the Serbian Orthodox were more prepared to commit various deeds that indicated a willingness to make religious sacrifices (Table 4).

TABLE 4: Mean value for affiliates, and for the very religious in willingness for religious sacrifice, by item and country confessional samples

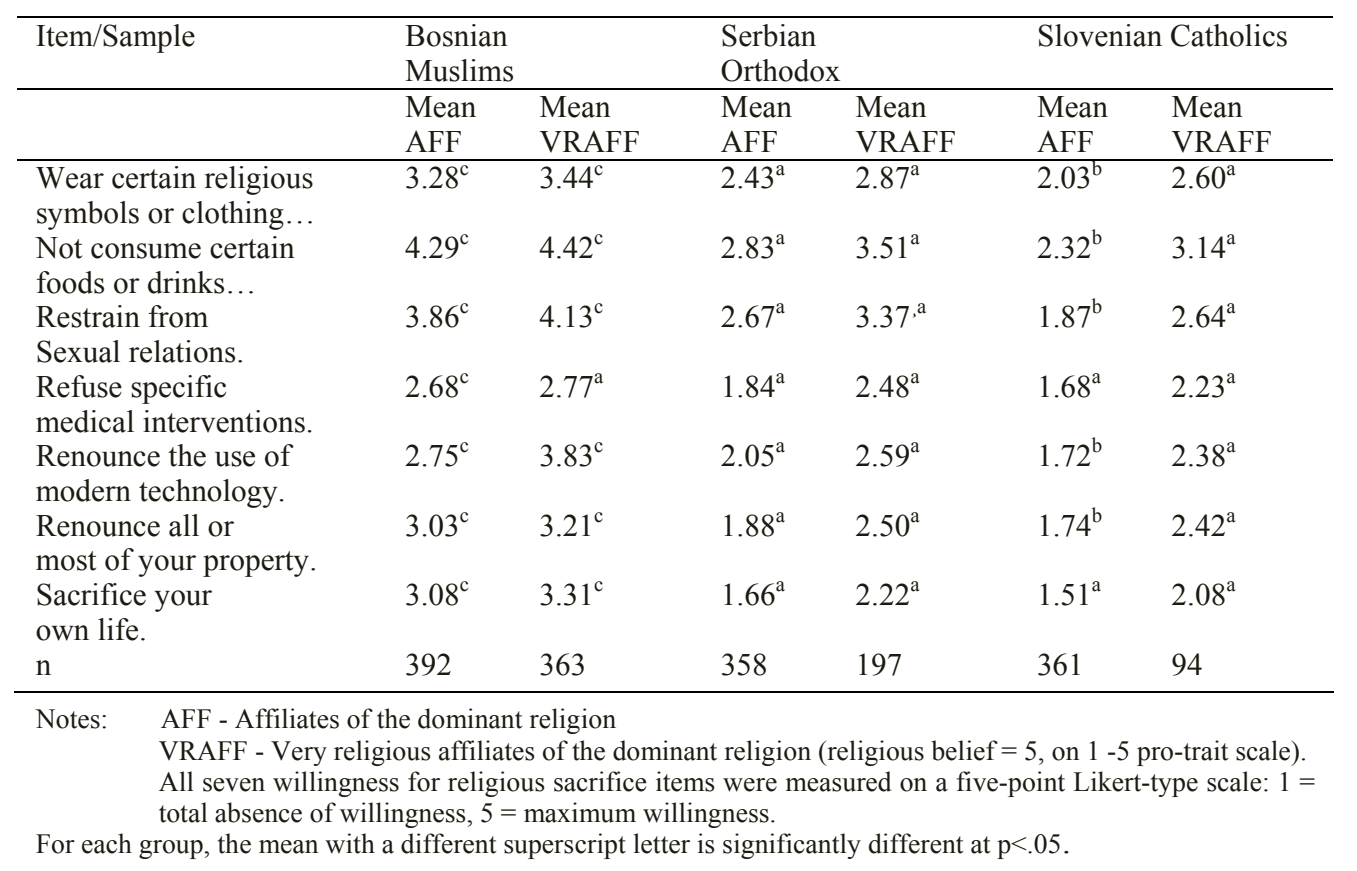

Results indicated that Serbian Orthodox affiliates were not very willing to commit sacrifices on behalf of their religion. Not only did they attain scores above normative means only twice (only Slovenians indicated lower means), but they were also unwilling to commit the ultimate sacrifice - to sacrifice their own lives, which as both Mitrović (1996) and Vrcan (1995) argued, should have been central for the Serbian Orthodox. In addition, even very religious subjects who expressed 
Sergej Flere, Rudi Klanšek, Serbian Orthodox Religiousness...

moderate willingness as their mean scores were also significantly $(p<.001)$ below the normative mean, in contrast with o mean scores found in the Muslim sample. Results thus implied that sacrificial acts did not seem very plausible among Serbian Orthodox, at least not to the extent that was found for Bosnian Muslims. Again, it seemed probable that it was the prevalence of general religiousness in the environment, its magnitude and strength, that chiefly determined the level of willingness and that consequentiality depended particularly on whether the entire environment was permeated by religiousness, whether or not it was a "moral community."

Civil religion

Results pertaining to the analysis of civil religion indicated that, on the average, the Serbian Orthodox did not differ significantly $(\mathrm{p}<.05)$ from Bosnian Muslims, since they attained a mean score of $\mathrm{M}=13.2$ while Bosnian Muslims attained $M=12.7$. Both samples differ significantly from Slovenian Catholics who attained mean score of $\mathrm{M}=9.5$.

Consequently, results did not conform to Vrcan's assertion (1995: 365) that all of Serbian Orthodoxy boiled down to civil religion as defined by Bellah (1967). Vrcan wrote in a tone allowing for the Church institution and Serbian intellectuals to be held responsible for such a reduction of religion. Such endeavors in Serbia were indisputably present; however, at the level of empirical awareness at the time of our research, they do not find empirical support. Next, if civil religion were to permeate Serbian Orthodox religiousness, this would also mean that there would be a close association between civil religion and religious belief. Follow-up analysis confirmed that this could be true (correlation coefficients between religious belief and civil religion were significant in all samples); however, the strength of such correlation for the Serbian Orthodox was second lowest among the samples (Slovenian Catholics: $\mathrm{r}=.37, \mathrm{p}<.001$; Serbian Orthodox: $\mathrm{r}=.33, \mathrm{p}<.001$; Bosnian Muslims: $\mathrm{r}=.27, \mathrm{p}<.001$ ).

Consequently, no real differences that would support this type of exceptionalism among the Serbian Orthodox could be identified at this point. In order to fully explore the whole spectrum of the phenomena at hand, we decided to analyze some distinctive traits that were not foreseen in the theoretical positions already cited but that could be identified as potentially interesting for the current study and further research.

\section{Buying religious objects}

When asked about the frequency of buying religious objects and souvenirs (see Appendix), the Serbian Orthodox were the only ones to respond, on average with a value above the normative mean at 3.0, followed by the otherwise very religious Bosnian Muslims at 2.5. We assumed that this may have to do with the Serbian Orthodox attribution of holiness to such objects, in line with Orthodox teaching and practice about icons and similar objects.

\section{God of Anger}


We asked respondents to respond to the statement 'Sometimes I feel God is angry at me'. The statement is indicative of guilt religiousness and of an angry, unforeseeable, punishing understanding of God, as is present in the Old Testament. This image also prevailed during the first centuries of Christianity, whereas the notions of purgatory and mercy in some strands of Christianity, particularly within Catholicism, later modified this idea, including the literal understanding of the "last judgment".

Among Muslims, there is no direct idea of purgatory, but there is a concept of an intermediate position ( $a^{\prime} r a f=$ heights), which may be a functional substitute for later Christian changes in the concept of justice (which the Orthodox have not accepted). Again, Serbian respondents peaked on this element of religious belief and feeling (see Figure 1).

FIGURE I: Error bar on agreement with statement "Sometimes

I feel God is angry at me", by country confessional samples

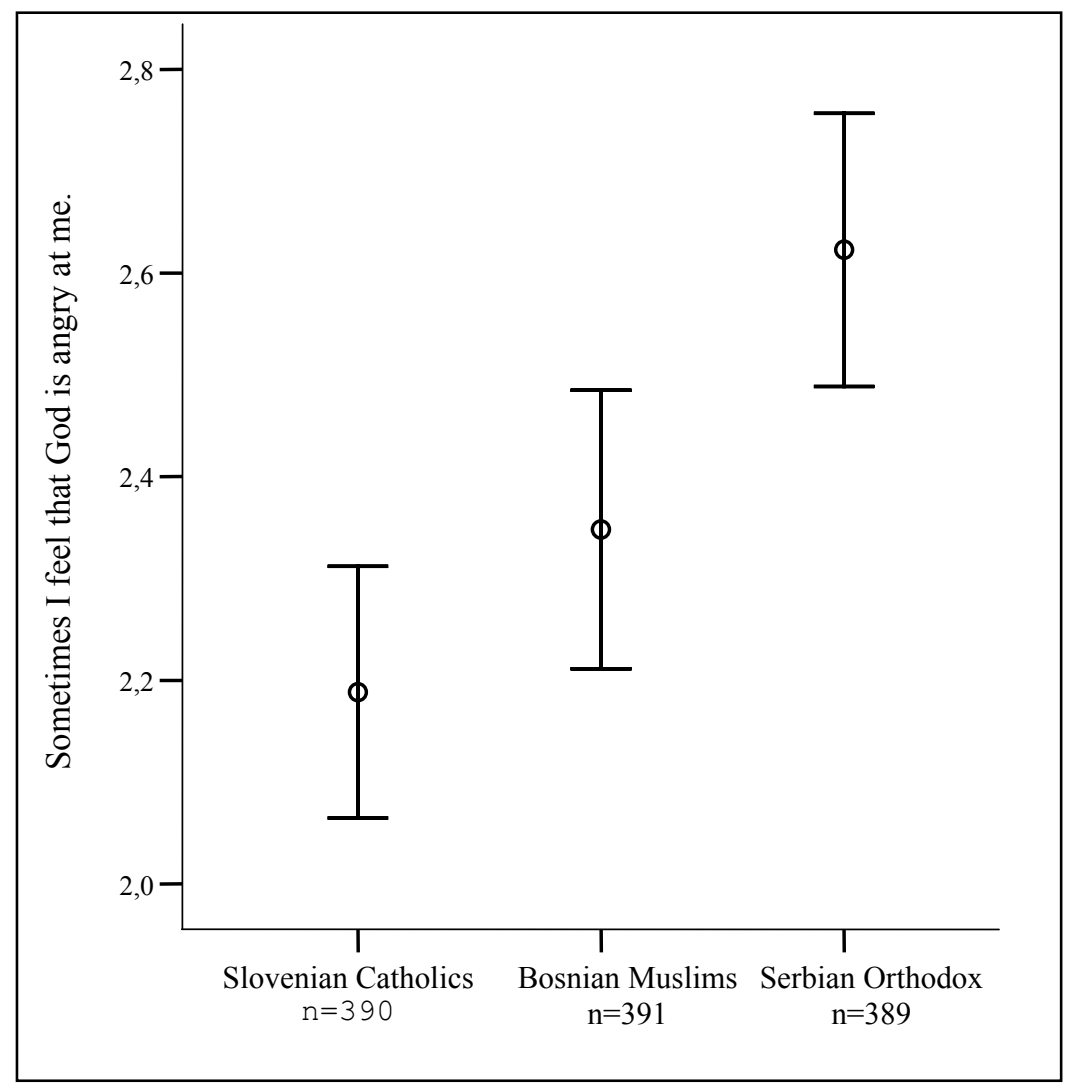

Note: The range is 1-5 in the pro-trait direction. Circles indicate means; vertical lines indicate standard deviations. All means differences are significant at $\mathrm{p}<05$. level. 
Sergej Flere, Rudi Klanšek, Serbian Orthodox Religiousness...

Post hoc tests further revealed differences among respondent groups. The mean difference between Orthodox Serb believers and Catholic Slovenians amounted to $.36(p<.05)$ while the mean difference between Orthodox Serb believers and Bosnian Muslims amounted to $.47(\mathrm{p}<.001)$. Consequently, it may be argued that this was not a random finding. We believe that it has to do with the understanding of God. In studying popular Serbian piety, for instance, the ethnologist Bandić writes that among Serbs, "Christian beings have taken on pagan traits, significantly contrasting to their likeness in the Christian teaching. The Christian God himself is no exception" (Bandić 1991: 146). Furthermore, he writes that God "... curses those who have offended him...he is more like a mighty ruler... and no one skips his justice" (Bandič 1991: 193). It is thus possible to argue that the popular Serbian Orthodox comprehension of God is primarily a comprehension that is filled by fear of punishment. This is also the context for understanding the use of the saying "Ima Boga!" (God does exist!), which is invoked exclusively when someone is unexpectedly punished or afflicted by misfortune after having committed deeds considered inexcusable, having thus far evaded due punishment. This may be the basis for understanding some other traits of Serbian Orthodox belief, including the situation we encountered with religious motivation.

Possibly this difference between Eastern and Western Christians was not to be expected theologically, since Eastern Christianity (in contrast to Western) teaches that humans did not inherit Adam's sin directly, but that "it was the result of the sin of our first human parents...that passed on to human beings" (Campbell 1996: 49). The Orthodox doctrine of theosis may in principle sound anthropologically optimistic, as the possibility of human attainment of Godliness, but in fact it underscores the sinfulness of man, particularly as it does not indicate a way, a method of regaining Godliness. Moreover, one could expect such a finding, considering Orthodoxy's generally relative greater truthfulness to original Christianity in stressing the sinful, fallen nature of man and his loss of holiness, loss of similarity to God etc. Additionally, one should note the extent to which pre-Christian belief is layered in empirical Orthodoxy. One needs to respond to the generality of such a comprehension of God by asking: is this typical of Eastern Orthodoxy in general, or is it a peculiarity of Serbian Orthodox religiousness? Although we do not have solid data, by itself the famous dictum by Dostoyevsky, "If God did not exist everything would be permitted" indicates the same way of thinking, one that disregards this-worldly justice and finds it only in God. Rancour-Laferriere, analyzing religious art, concluded that "among Russian Orthodox believers to this day a sense of guilt is pervasive..." (Rancour-Laferriere 2003: 14). Thus we may assume that this understanding of God holds at least for Slavic Eastern Orthodoxy. To sum up, we have found certain peculiarities dealing with an angry, condemning concept of God and a marked psychologically extrinsic tendency in religiousness among the Serbian Orthodox. On this basis, we hypothesize that those traits are indicative of a religiousness inculcated by anxiety, which we illustrate in Table 5. 
Социолошки преглед, vol. XLII (2008), nо. 1, стр. 27-44

TABLE 5: Zero order correlations for the relationship between trait anxiety and chosen measures of religiousness, by country confessional samples

\begin{tabular}{llllll}
\hline $\begin{array}{l}\text { Sample/Religious } \\
\text { Orientation }\end{array}$ & $\begin{array}{l}\text { Intrinsic } \\
\text { orientation }\end{array}$ & $\begin{array}{l}\text { Personal } \\
\text { extrinsic } \\
\text { orientation }\end{array}$ & $\begin{array}{l}\text { Other- } \\
\text { oorldly } \\
\text { orientation }\end{array}$ & $\begin{array}{l}\text { Experiencing } \\
\text { divine } \\
\text { presence } \\
\text { item }\end{array}$ & $\begin{array}{l}\text { God's } \\
\text { anger } \\
\text { item }\end{array}$ \\
\hline Bosnian Muslims & $-.155^{* *}$ & .042 & .020 & .010 & $.271^{* *}$ \\
& $(\mathrm{n}=369)$ & $(\mathrm{n}=389)$ & $(\mathrm{n}=385)$ & $(\mathrm{n}=375)$ & $(\mathrm{n}=379)$ \\
Serbian Orthodox & $.165^{* *}$ & $.183^{* *}$ & $.165^{* *}$ & $.152^{* *}$ & $.290^{* *}$ \\
& $(\mathrm{n}=369)$ & $(\mathrm{n}=373)$ & $(\mathrm{n}=379)$ & $(\mathrm{n}=378)$ & $(\mathrm{n}=383)$ \\
Slovenian Catholics & .034 & $.150^{* *}$ & .077 & .059 & $.288^{* *}$ \\
& $(\mathrm{n}=359)$ & $(\mathrm{n}=359)$ & $(\mathrm{n}=361)$ & $(\mathrm{n}=360)$ & $(\mathrm{n}=361)$ \\
\hline
\end{tabular}

Notes: $\quad * *$ Correlation is significant at the 0.01 level (two-tailed).

Results indicated that the Serbian Orthodox sample was the only one of the three samples analyzed where a significant positive relationship between anxiety and different indicators of religiousness could be observed. The other three groups showed significant positive correlations only with regard to the item on which the Serbians have the highest score - God's anger.

Though fear, God-fearing in particular, is a universal feature of monotheism, this seems to have been down-played in the other environments we considered. On the other hand, God-fearing is alive and well in Serbian Orthodoxy, associated with anxiety and an extrinsic psychological religious orientation. This is a markedly different picture from the one of quiet and apophasis thought to be theologically typical of Orthodoxy.

\section{CONCLUSION}

The current study tried to empirically identify the peculiarities of Eastern Orthodoxy that have often been implied by various authors. Results indicated that the Serbian Orthodox were not radically peculiar, as would follow from Tomka (2006), who demanded a special methodology for the study of Eastern Christianity.

According to different indicators used in the study, the level of religiousness was somewhere near the European average. In addition, findings indicating that the Serbian Orthodox were closer on most measures to Slovenian Catholics than to Bosnian Muslims complement the initially indicated WVS findings. Consequently, 
Sergej Flere, Rudi Klanšek, Serbian Orthodox Religiousness...

some assertions that have been made about Eastern and Serbian Orthodoxy were not confirmed: mystical experience, permeation by civil religion and other-worldly orientation were not particularly marked or distinctive. Willingness to commit religiously meaningful deeds and sacrifices was also not marked.

Most of our findings could be explained by the lack of a "moral community" (Stark et al. 1982). Thus, at the same levels of belief in God, the Serbian Orthodox (and Slovenian Catholics) demonstrated less religious "substance": readiness to sacrifice, other-worldly orientation, divine experience - all of which may be considered stricter substantive measures of religiousness. We thus may speculate that, beside this early Christian comprehension of God and pre-Christian elements present in belief and piety, there might also be a lack of contemporary psychological approaches in the practice of this religion, a situation which might contribute to the positive link between trait anxiety and religiousness.

Nevertheless, it is questionable how much of our findings can be generalized to Eastern Orthodoxy as a whole. As to the magnitude of religiousness, there were indications of religiousness being more and less present generally than among the Serbs, but as to the crucial issue of religious belief and the concept of God, we are inclined to speculate that we are on the right track for most Eastern groups.

APPENDIX: Measures applied

\begin{tabular}{|l|l|}
\hline WVS item applied on population sample & $\begin{array}{l}\text { The answers for the item were formatted } \\
\text { from 1 (not at all) - 10 (very important). }\end{array}$ \\
\hline How important is God in your life? & $\begin{array}{l}\text { The questions were with answers in 1 (not at } \\
\text { all) to } 5 \\
\text { (absolutely) format. }\end{array}$ \\
\hline Religious belief 4 samples data collection & $\begin{array}{l}\text { Do you believe in God? } \\
\text { Do you believe that people have a soul? } \\
\text { Do you believe in life after death? } \\
\text { Do you believe in hell? }\end{array}$ \\
& \multicolumn{2}{|l}{} \\
\hline $\begin{array}{l}\text { Gorsuch \& McPherson Intrinsic and Psychological Extrinsic Items (without Extrinsic Other items) } \\
\text { (1989) }\end{array}$ \\
\hline
\end{tabular}


Сочиолошки преглед, vol. XLII (2008), no. 1, стр. 27-44

\begin{tabular}{|c|c|}
\hline $\begin{array}{l}\text { I enjoy reading about my religion. } \\
\text { It is important to me to spend time in private thought } \\
\text { and prayer. } \\
\text { I have often had a strong sense of a Divine presence. } \\
\text { I pray mainly to gain relief and to receive protection. } \\
\text { I try hard to live all my life according to my religious } \\
\text { beliefs. } \\
\text { What religion offers me most is comfort in times of } \\
\text { trouble and sorrow. } \\
\text { Prayer is for peace and happiness. } \\
\text { My whole approach to life is based on my religion. }\end{array}$ & $\begin{array}{l}\text { The items all contained } 1-5 \text { pro-trait } \\
\text { answers. }\end{array}$ \\
\hline \multicolumn{2}{|l|}{ Other-worldly orientation items } \\
\hline $\begin{array}{l}\text { Heaven is my home and so I don't worry much about } \\
\text { this world. } \\
\text { What happens to me in this life is not really important } \\
\text { to me compared to what awaits me in the afterlife. }\end{array}$ & The items contain 1 to 5 pro-trait answers. \\
\hline \multicolumn{2}{|l|}{ Civil religion items } \\
\hline $\begin{array}{l}\text { Our country has a special covenant with God. } \\
\text { It is not really possible to be a good patriot without } \\
\text { being a true follower of my religion. } \\
\text { It might be said that our country does not comply } \\
\text { with all of its religious duties. } \\
\text { Each individual of my nationality should belong to } \\
\text { my religion. } \\
\text { God has intervened in the history of my nation by } \\
\text { testing its true faith. }\end{array}$ & The items contain 1 to 5 pro-trait answers. \\
\hline Readiness for religious sacrifice items & \\
\hline
\end{tabular}


Sergej Flere, Rudi Klanšek, Serbian Orthodox Religiousness...

\begin{tabular}{|c|c|}
\hline $\begin{array}{l}\text { Would you do some of the following things for the } \\
\text { sake of your religion? } \\
\text { Wear certain religious symbols or clothing even at } \\
\text { occasions where it might embarrass you. } \\
\text { Not consume certain foods or drinks for a longer } \\
\text { period of time. } \\
\text { Restrain from sexual relations. } \\
\text { Refuse specific medical interventions } \\
\text { Renounce the use of modern technology. } \\
\text { Renounce all or most of your property } \\
\text { Sacrifice your own life. }\end{array}$ & The items contain 1 to 5 pro-trait answers. \\
\hline \multicolumn{2}{|l|}{ Buying religious objects item } \\
\hline $\begin{array}{l}\text { How often do you buy religious } \\
\text { Objects (statuettes, symbols, jewelry) }\end{array}$ & $\begin{array}{l}\text { The item answers were formatted in } 1 \\
\text { (never) to } \\
5 \text { (very often). }\end{array}$ \\
\hline God of anger item & \\
\hline
\end{tabular}

\section{REFERENCES}

Allport, Gordon W. and James M. Ross. 1967. "Personal Religious Orientation and Prejudice." Journal of Personality and Social Psychology. 5: 432-443.

Bandić, Dušan. 1991. Narodna religija Srba u sto pojmova. Beograd: Nolit.

Bellah, Robert N. 1967. »Civil Religion in America«. Daedelus, 96(1): 1-21.

Blagojević, Mirko. 2005. Religija i crkva u transformacijama društva. Beograd: Filip Višnjić.

Bogdanović, Dimitrije. 1991. Pravoslavna duhovnost u iskušenjima našeg doba. Gradina, 26, 33-43.

Campbell, Ted A. 1996. Christian Confessions: A Historical Introduction. Louisville KE: Westminster John Knox Press.

Donahue, Michael J. 1985. "Intrinsic and Extrinsic Religiousness: The Empirical Research." Journal for the Scientific Study of Religion. 24: 418-423.

Đorđević, Dragoljub B. 2000. "Sociološki uvid u kulturu pravoslavlja (Srpsko pravoslavlje i SPC)." Teme. 24: 161-175.

Đorđević, Dragoljub, B. Pravoslavlje izmedju neba i zemlje. Nis: Gradina.

Flere, Sergej and Lavrič, Miran (2007). "Operationalizing Civil Religion at Cross-Cultural Level." Journal for the Scientific Study of Religion, 46, 596-604.

Gehrig, Gail. 1981. The American civil religion debate: A source for theory construction, Journal for the Scientific Study of Religion 20 (1): 51-63. 
Gorsuch, Richard L. and McPherson, Susan E. 1989. "Intrinsic/extrinsic Measurement: I/E Revised in Single Item Scales." Journal for the Scientific Study of Religion, 28: 348354.

Inglehart, Ronald, et al. (2004). WORLD VALUES SURVEYS AND EUROPEAN VALUES SURVEYS, 1999-2001 [Computer file]. ICPSR version. Ann Arbor, MI: Institute for Social Research [producer], 2002. Ann Arbor, MI: Inter-university Consortium for Political and Social Research [distributor], 2004.

Makrides, Vassilis. 1999. „Ambiguous Reception and Troublesome Relationship: the Sociology of Religion in Eastern Orthodox Europe. Pp. 139-154. In Sociology and Religions. Edited by L. Voye and J. Billiet. Leuven: Leuven University Press.

Mitrović, Milovan. 1996. »Srpska vera, crkva i nacija«, Pp. 222-229 in Religija, crkva, nacija, edited by B. Đurović. Niš: JUNIR.

Mladenović, Radoš \& Ćulibrk, Jovan (Eds.) (1996). Jagnje Božije i zvijer iz bezdana. Filozofija rata. Cetinje: Svetigora.

Radisavljević Ćipirazović, Dragica. 2002. 'Religija i svadonevni život: vezanost ljudi za religiju i crkvu krajem devedesetih'. Pp. 215-239 in Srbija krajem milenijuma: razaranje društva, promene i svakodnevni život. Edited by M. Milić and S. Bolčić. Beograd: Institut za sociološka istraživanja FF.

Rancour-Laferriere, Daniel. 2003. "The Moral Masochism at the Heart of Christianity: Evidence from Russian Orthodox Iconography and Icon Veneration”. Journal for the Psychoanalysis of Culture and Society. 8: 12-23.

Republički zavod za statistiko Republike Srbije (RZSRS). 2003. Stanovništvo. Beograd: Republički zavod za statistiko Republike Srbije.

Spielberger, Charles D. 1983. Manual for the State-Trait Anxiety Inventory. Palo Alto, CA: Consulting Psychologists Press.

Stark, Rodney, Lori Kent, and Daniel Doyle. 1982. »Religion and Delinquency: The Ecology of a 'Lost' Relationship«, Journal of Research in Crime and Delinquency. 19, $5-23$.

Stark, Rodney. 2001. “Gods, Rituals and the Moral Order". Journal for the Scientific Study of Religion. 40, 619-636.

Stark, Rodney. 2004. SSSR Presidential Address, 2004: Putting an End to Ancestor Worhip. Journal for the Scientific Study of Religion. 43, 465-475.

Vrcan, Srđan. 1995. „A Christian Confession Possessed by Nationalistic Paroxysm: The Case of Serbian Orthodoxy«, Religion, 25, 357-370.

Sergej Flere

Su $m$ m ary

University of Maribor, Slovenia

Rudi Klanjšek

University of Maribor, Slovenia

\section{СРПСКА ПРАВОСЛАВНА РЕЛИГИОЗНОСТ: ЕМПИРИЈСКИ И УПОРЕДНИ ПОРТРЕТ}

У овом раду Српска православна црква је предмет истраживања помоћу различитих мерила религиозности. Пошто су српску религиозност ситуирали у контекст Истраживања светских вредности (World Values Survey), извршено је поређење узорка групе студената с универзитета јужне Србије с узорцима студената преостале две вере: босанско-муслиманске и словеначко-католичке. Коришћењем WVS инструме- 
Sergej Flere, Rudi Klanšek, Serbian Orthodox Religiousness...

ната резултати показују да су Срби православци више религиозни него нерелигиозни; на основу својих података и сложенијих инструмената Срби православци су религиознији од Словенаца католика, али мање од Босанаца муслимана, мада Срби православци по неким тачкама исказују теенденцију надилажења нормативних мерила. Насупрот тврдњама из литературе (Mitrovic 1995; Vrcan 1995; Tomka 2006) нису нарочито изражени мистицизам, религиозно искуство и цивилна религија. Срби православци исказују висок ниво екстринсичне психолошке религиозности и религиозности кривице, а у оба случаја исказују значајну позитивну корелацију с анксиозношћу.

Кључне речи: Срби православци, религиозност, верска оријентација, религиозност кривице, религиозна доследност. 